\title{
12
}

\section{Regional development in China}

\section{The role of FDI, exports and spillover effects}

\author{
Qing Zhang
}

This chapter develops a model of provincial growth in China taking into account the differing policy treatment of China's regions, the contribution of foreign direct investment (FDI) and exports to provincial growth, and the spillover effects on different regions.

The motivation for studying the growth of China needs little embellishment. The opening of China's markets in 1978 created the almost unprecedented prospect of new market and investment opportunities for the rest of the world. ${ }^{1}$ Until the East Asian currency crisis, China had fulfilled its growth potential by recording growth outcomes that made China the fastest growing economy in the world. The East Asian crisis and China's response to it, including the resistance of the Chinese government to devaluation, slowed China's overall growth rate but China made it through the crisis and has continued with the fastest growth in East Asia

Research on the subject of export-led growth has increased steadily since 1970 , and empirical studies in particular provide conflicting evidence. The studies by Voivodas (1973), Michaely (1977), Balassa (1978), Tyler (1981), Kavoussi (1984) and Feder (1982) support the export-led growth hypothesis. The export-led growth hypothesis has been a widely accepted explanation in the development literature after the success stories of several newly industrialised countries (NICs). Some empirical investigations, however, fail to find any positive impact of exports on economic development. The reasons for these different results have been discussed in a number of recent studies (Kohli and Singh 1987; Boulding 1992; Greenaway and Sapsford 1994; Poon 1995; Yaghmaian 


\section{Dilemmas of China's Growth in the Twenty-First Century}

and Ghorashi 1995). These authors argue that the relationship between exports and economic growth depends on the level of development and the economic structure of a country. Export expansion may not impact on economic growth effectively at a low level of development, but the contribution of exports to economic growth will be of great significance when economic development progresses. Most of the studies mentioned above are conducted using multicountry samples. A few studies have examined the case for the NICs (Chen and Tang 1990; Dutt and Ghosh 1996). Consensus has not been reached on the impact of export expansion on economic growth in the context of China, a nation which is reforming its centrally planned economy.

This study is based on provincial rather than national data. The preference for provincial data is driven by two considerations: the limited nature of Chinese national data, and the diverse experience of the Chinese provinces in relation to the receipt of FDI and export growth. In terms of the former, reliable national data about FDI and exports tends to only be available from 1980 onward, and is then usually recorded on an annual basis. FDI and export data are accessible for the provinces and cities of China over the same period so that time series and cross-section data can be pooled as a resource for panel data regression modeling. Panel data sets have sufficient degrees of freedom to allow for reliable inferences to be drawn. This procedure is applied in the formal study cited here.

The development experiences of the Chinese provinces vary so greatly that an aggregate study of economic growth for China as a whole would be devoid of any meaning. An aggregate study, including FDI and exports in China, simply misses the basic point: that the distribution of inward FDI across China's provinces is unevenly distributed. Analysts of the Chinese economy generally concur with the view that the provinces of China are at present an appropriate basis for Chinese macro studies at present. Sun and Chai (1998) and Kam Ki Tang (1998) have undertaken two recent studies that support this view. The adoption of Zhang and Felmingham's (1999) grouping of the Chinese provinces is also appropriate. These authors group the individual provinces functionally. The groupings that apply are the high FDI provinces (HFDI), the medium FDI group (MFDI) and the low FDI grouping (LFDI). ${ }^{2}$ This choice was based on functional characteristics, namely the differing policy treatment of the three regions and the concentration of inward FDI in the HFDI provinces. Zhang and Felmingham's study indicates that this grouping should be preserved.

The grouping of provinces by location and function dictates that this study takes into account the potential spillover effects of growth in one region or province on growth in others. This is a most important policy consideration as any policy that encourages inward FDI in one region will potentially impact on other regions, provided spillover effects are evident. This study extends the models developed by Feder (1982) to allow for interregional spillovers. 


\section{Regional development in China}

\section{A model of export expansion, growth and spillover effects}

The most commonly applied approach for empirical investigations of exports and economic development in the PRC is based on the neoclassical aggregate production function (NAPF), adding the indicator of export performance on the right-hand side of the NAPF equation to explain the possibility of exportled economic growth.

The model used in this study is an extended version of Feder's (1982) model. The advantage of Feder's model is that it allows for the separate measurement of a sector externality effect and a factor productivity effect, both of which are associated with export expansion. Feder's model is augmented with the addition of FDI as an independent variable in this study. This involves the disaggregation of total investment into FDI and domestic investment leading to the inclusion of a third relative marginal productive condition in Equation 12.8.

First, the economy is assumed to consist of two sectors: the export and the non-export sectors. So overall output (GDP) is the summation of the output from each sector.

Let $Y=G D P, N=$ output of the non-export sector, and $X=$ output of the export sector. Thus,

$$
\mathrm{Y}=\mathrm{N}+\mathrm{X}
$$

It is assumed that there are two kinds of capital stock in each sector: foreign capital $\left(\mathrm{K}^{*}\right)$ and domestic capital $\left(\mathrm{K}^{*}\right)$. The production functions for sector $\mathrm{X}$ and $\mathrm{N}$ are specified as the functions of the factors allocated to each sector with an externality from sector $\mathrm{X}$ to $\mathrm{N}$.

$$
\begin{aligned}
& N=F\left(K_{n}^{-}, K^{*}, L_{n}, X\right) \\
& X=G\left(K_{x^{n}}^{-}, K^{*}, L_{x}\right)
\end{aligned}
$$

where $\mathrm{K}_{n}^{-}, \mathrm{K}_{\mathrm{x}}^{-}$are domestic capital stock in $\mathrm{N}$ and $\mathrm{X}$ sectors, respectively, $\mathrm{K}^{*}, \mathrm{~K}_{\mathrm{x}}^{*}$ are foreign capital stock in $\mathrm{N}$ and $\mathrm{X}$ sectors, respectively, and $\mathrm{L}_{\mathrm{n}}, \mathrm{L}_{\mathrm{x}}$ are labour force in $\mathrm{N}$ and $\mathrm{X}$ sectors, respectively.

The assumptions here are that the domestic capital stock and FDI are used in both sectors and the total labour force is distributed across both the export and non-export sectors. So $\mathrm{K}^{-}=\mathrm{K}_{\mathrm{n}}^{-}+\mathrm{K}_{\mathrm{x}^{\prime}}, \mathrm{K}^{*}=\mathrm{K}_{\mathrm{n}}{ }+\mathrm{K}_{\mathrm{x}^{\prime}}, \mathrm{L}=\mathrm{L}_{\mathrm{n}}+\mathrm{L}_{\mathrm{x}}$.

Let the dot notation symbolise the time change of the specified variables.

$\dot{Y}=\dot{N}+\dot{X}$

Taking total differentials of Equations 12.2 and 12.3 with respect to time, and letting $\mathrm{I}^{-}$and $\mathrm{I}^{*}$ represent the change of domestic capital and FDI $\left(\dot{K}^{-}, \dot{K}^{*}\right)$, respectively, yields

$$
\begin{aligned}
& \dot{N}=\mathrm{F}_{\mathrm{k}}{ }^{-} \mathrm{I}_{\mathrm{n}}{ }^{-}+\mathrm{F}_{\mathrm{k}}{ }^{*} \mathrm{I}_{\mathrm{n}}^{*}+\mathrm{F}_{\mathrm{L}} \dot{L}_{\mathrm{n}}+\mathrm{F}_{\mathrm{x}} \dot{X} \\
& \dot{X}=\mathrm{G}_{\mathrm{k}}{ }^{-} \mathrm{I}_{\mathrm{x}}{ }^{-}+\mathrm{G}_{\mathrm{k}}{ }^{*} \mathrm{I}_{\mathrm{x}}^{*}+\mathrm{G}_{\mathrm{L}} \dot{L}_{\mathrm{x}}
\end{aligned}
$$




\section{Dilemmas of China's Growth in the Twenty-First Century}

In Equation 12.5, $\mathrm{F}$ refers to the marginal productivity with subscripts $\mathrm{K}$ , $\mathrm{K}^{*}, \mathrm{~L}$ standing for the input of domestic capital, FDI and labour in the nonexport sector. In Equation 12.6, G refers to the marginal productivity with subscripts $\mathrm{K}, \mathrm{K}^{*}, \mathrm{~L}$ representing the input of domestic capital, FDI and labour in the export sector.

Substituting Equations 12.5 and 12.6 into Equation 12.4 yields

$Y=\mathrm{F}_{\mathrm{k}} \mathrm{I}_{\mathrm{n}}{ }^{-}+\mathrm{F}_{\mathrm{k}}{ }^{*} \mathrm{I}_{\mathrm{n}}{ }^{*}+\mathrm{F}_{\mathrm{L}} L_{\mathrm{n}}+\mathrm{F}_{\mathrm{x}} X+\mathrm{G}_{\mathrm{k}} \mathrm{I}_{\mathrm{x}}{ }^{-}+\mathrm{G}_{\mathrm{k}}{ }^{*} \mathrm{I}_{\mathrm{x}}{ }^{*}+\mathrm{G}_{\mathrm{L}} L_{\mathrm{x}}$ (12.7)

A specific transformation is required if aggregate data is applied to estimate the sectoral marginal productivities. Suppose the respective marginal products in each sector are not the same, regardless of the source of the capital stock.

$\left(\mathrm{G}_{\mathrm{k}} / \mathrm{F}_{\mathrm{k}}^{-}\right)=\left(\mathrm{G}_{\mathrm{L}} / \mathrm{F}_{\mathrm{L}}\right)=\left(\mathrm{G}_{\mathrm{k}}{ }^{*} / \mathrm{F}_{\mathrm{k}}{ }^{*}\right)=1+\delta$

Equation 12.8 then shows that the ratios of marginal productivity of FDI, domestic capital and labour in sector $\mathrm{X}$ and $\mathrm{N}$ differ by $\delta$. The underlying argument is that marginal factor productivities are likely to be lower in the non-export sector. One major reason is that export firms are located in a highly competitive sector of the economy. Competition encourages innovation, adaptability and the efficient management of a firm's resources (Feder 1982). The various regulations and constraints such as credit and foreign exchange rationing (Balassa 1978) are another reason for the differences between sectoral marginal factor productivities. Export companies are disciplined through competition in the international markets. Consequently, the export sector is forced to be more efficient than sheltered domestic industries and so productivity is forced up in this sector.

To advance the model further, $G_{k}{ }^{*}, G_{k}$ and $G_{L}$ of Equation 12.8 are substituted into Equation 12.7 to yield

$$
\begin{aligned}
& Y=\mathrm{F}_{\mathrm{k}}\left(\mathrm{I}_{\mathrm{n}}{ }^{-}+\mathrm{I}_{\mathrm{x}}^{*}\right)+\mathrm{F}_{\mathrm{k}}^{*}\left(\mathrm{I}_{\mathrm{n}}^{*}+\mathrm{H}_{\mathrm{x}}^{*}\right)+\mathrm{F}_{\mathrm{L}}\left(\dot{L}_{\mathrm{n}}+\dot{L}_{\mathrm{x}}\right)+\mathrm{F}_{\mathrm{x}} \dot{X} \\
& +\delta\left(\mathrm{F}_{\mathrm{k}} \mathrm{I}_{\mathrm{x}}+\mathrm{F}_{\mathrm{k}} \mathrm{I}_{\mathrm{x}}^{*}+\mathrm{F}_{\mathrm{L}} L_{\mathrm{x}}\right) \\
& \dot{Y}=\mathrm{F}_{\mathrm{k}} \mathrm{I}^{-}+\mathrm{F}_{\mathrm{k}}{ }^{*}{ }^{*}+\mathrm{F}_{\mathrm{L}} \dot{L}+\mathrm{F}_{\mathrm{x}} \dot{X}+(\delta / \mathrm{I}+\delta)\left(\mathrm{G}_{\mathrm{k}} \mathrm{I}_{\mathrm{x}}^{-}+\mathrm{G}_{\mathrm{k}}{ }^{*} \mathrm{I}_{\mathrm{x}}{ }^{*}+\mathrm{G}_{\mathrm{L}} \dot{L}_{\mathrm{x}}\right)
\end{aligned}
$$

Since the last three variables involve sectoral data, which are not available yet, we substitute Equation 12.6 into Equation 12.10 and simplify to obtain

$$
\dot{Y}=\mathrm{F}_{\mathrm{k}} \mathrm{I}^{-}+\mathrm{F}_{\mathrm{k}}{ }^{*} \mathrm{I}^{*}+\mathrm{F}_{\mathrm{L}} L+[\mathrm{Fx}+(\delta / 1+\delta)] \dot{X}
$$

Note that the partial derivative of $F$ with respect to $X,\left(F_{x}\right)$, captures the sector-externality effect of export expansion and measures the positive externality of the export sector on the non-export sector. The symbol $\delta$ indicates the productivity differentials between the export and the non-export sectors-or the factor productivity effect-which measures the gain due to the higher productivity of factors in the export sector.

Now, let $\mathrm{F}_{\mathrm{k}}=\alpha_{1}, \mathrm{~F}_{\mathrm{k}}^{*}=\alpha_{2}, \mathrm{~F}_{\mathrm{L}}=\alpha_{3}, \gamma=[\mathrm{Fx}+(\delta / 1+\delta)]$, then Equation 12.11 can be simplified as 


\section{Regional development in China}

$$
\dot{Y}=\alpha_{1}{ }^{\mathrm{I}}+\alpha_{2} \mathrm{I}^{*}+\alpha_{3} \dot{L}+\gamma \dot{X}
$$

Equation 12.12 forms the basis of our estimation: $\alpha_{1}$ measures the marginal productivity of domestic capital in the non-export sector, while $\alpha_{2}$ measures the marginal productivity of foreign capital in the non-export sector. It is expected that both $\alpha_{1}$ and $\alpha_{2}$ will be positive, while $\alpha_{3}$ refers to the labour growth for Chinese total labour forces and $\gamma_{\text {represents the parameter for the }}$ export variable $(\dot{X})$. It includes both a sector-externality effect $\left(\mathrm{F}_{\mathrm{x}}\right)$ and the productivity differential $(\delta)$. Both should be positive and significantly different from zero since the hypothesis suggests that marginal productivities in the export sector are higher and that exports generate beneficial externalities to the non-export sector. If marginal productivities are equalised across sectors $(\delta=$ $0)$ and if there are no inter-sector externalities $\left(F_{x}=0\right)$ then Equation 12.12 will reduce to the transformed neoclassical production formulation of the sources of growth model with foreign capital stock. ${ }^{3}$ In fact, it is appropriate to identify the role of sector-externality and factor-productivity effects separately; $\gamma_{\text {can }}$ be decomposed at this stage on the assumption that exports affect the production of non-exports with constant elasticity $(\theta)$. The production function for the non-export sector will be

$\mathrm{N}=\mathrm{F}\left(\mathrm{K}_{\mathrm{n}}, \mathrm{K}_{\mathrm{n}}^{*}, \mathrm{~L}_{\mathrm{n}}, \mathrm{X}\right)=\mathrm{X}^{\theta} \Psi\left(\mathrm{K}_{\mathrm{n}}^{-}, \mathrm{K}_{\mathrm{n}}^{*}, \mathrm{~L}_{\mathrm{n}}\right)$

Now the partial derivative of $F$ with respect of $\mathrm{X}$ is given by

$\mathrm{F}_{\mathrm{x}}=\partial \mathrm{N} / \partial \mathrm{X}=\theta(\mathrm{N} / \mathrm{X})$

Because of Equation 12.1,

$\mathrm{F}_{\mathrm{x}}=\theta(\mathrm{Y}-\mathrm{X}) / \mathrm{X}$

Substituting Equation 12.15 into Equation 12.11 and after some manipulation, Equation 12.11 can be rewritten as

$$
\dot{Y}=\alpha_{1} \mathrm{I}^{-}+\alpha_{2} \mathrm{I}^{*}+\alpha_{3} \dot{L}+\theta(\mathrm{Y}-\mathrm{X})(\dot{X} / \mathrm{X})+(\delta / 1+\delta) \dot{X}
$$

So Equation 12.16 is the basis of estimation allowing for the separate measurement of $\delta$.

\section{Data and methodology}

\section{Data and definition of variables}

The data for 29 Chinese provinces, municipalities and autonomous regions (referred to as provinces) in China over the period 1984-98 are utilised in this study. Chongqin is a municipal city in China but is excluded from this study since it was only established in 1997. Because it was a part of Sichuan province prior to achieving its city status, we treat it as part of Sichuan province in order to keep the data consistent. Tibet is not included in this study since at this point in time, it has no FDI.

The data on Chinese provincial GDP, CPI, domestic investment, FDI, 


\section{Dilemmas of China's Growth in the Twenty-First Century}

population and exports are taken from the various sources. ${ }^{4}$ The GDP deflators for China and United States for the period 1983-98 are obtained from the DX data file (2000), WBWT: Data Table 2 and Data Table 3, respectively. The exchange rate for Chinese yuan RMB in terms of US dollars for the year 1995 is used in this study (IMF 2000).

By and large, Chinese statistics are internally consistent and accurate enough for empirical work (Chow 1993). One concern regarding data is the limited time series. Since panel data sets are employed in this research, the limited sample data restrictions need to be overcome. The models for this study can not only be applied to the whole sample consisting of 435 observations but also to the three regions defined later in this section. The panel of the HFDI, the MFDI and the LFDI provinces when combined with 15 time-series observations produces data sets of the following size: the HFDI region (120 observations), the MFDI region (195 observations) and the LFDI region (120 observations). The panel data constitutes a sufficiently large data set for the current study.

The variables are defined in the following way.

- $Y$ is the first difference of real provincial GDP (billion yuan RMB) in China for the period 1984-98. The year 1995 is specified as the base year. It is calculated as follows. The current values of GDP for each province are first converted into real values using 1995 constant prices for each province. Then $\dot{Y}_{t}=G D P_{t}-G D P_{t-1}$, where GDP, $\mathrm{GDP}_{\mathrm{t}-1}$ are the real GDP for the two consecutive years respectively.

- I-is the change in domestically financed capital stock (billion yuan RMB) in each province for the period 1984-98 in real terms, with 1995 as the base year. The current domestically financed total fixed asset investment is converted into real terms using the GDP deflator as a proxy for the total fixed asset investment deflator, because total fixed investment deflators are only available from 1992 for the Chinese provinces.

- I* refers to the change in foreign capital stock which is specified as real Chinese provincial inward FDI (billion yuan RMB). The initial FDI data are nominal data measured in millions of US dollars. This variable is obtained as follows. First, the current values of FDI are deflated using the US GDP deflator $(1995=100)$. Then the real values of FDI in millions of US dollars for each province are transferred to the real values measured in billion yuan RMB. The exchange rate of yuan RMB with respect to US dollars in 1995 is employed here to exclude the effect of inflation and the instability of the exchange rate.

- $L$ is the first difference of the total labour force in each province of China for the period 1984-98. It is calculated as $\dot{L}=\mathrm{L}_{\mathrm{r}}-\mathrm{L}_{\mathrm{t}-\mathrm{1}}$, where 


\section{Regional development in China}

$\mathrm{L}_{\mathrm{t}}$ is the labour force in the current year and $\mathrm{L}_{\mathrm{t}-1}$ stands for the labour force in the previous year. We use the supply side of labour force data because the analysis adopts a supply side description of changes in aggregate output and also because the unemployment data for provinces is incomplete. Provincial population growth is used as a proxy for total labour force growth in each province on the assumption that the participation rate remains the same.

- $\dot{X}$ refers to the first difference of real exports for the period 1984 98. Export data are originally expressed in millions of US dollars at current values. So first, the real values of exports for the provinces are found by dividing the current exports by the US GDP deflator (1995 $=100$ ). Then exports are expressed in real billions of yuan RMB using the exchange rate of yuan RMB to US dollars in 1995. This is an attempt to avoid the effect of inflation and the instability of the exchange rate. Then, $\dot{X}=\operatorname{Exp}_{t}-\operatorname{Exp}_{t-1}$, where $\operatorname{Exp}_{t}, \operatorname{Exp}_{t-1}$ are real exports in consecutive years.

\section{Methodology}

The major part of this study is focused on investigating the roles of exports and FDI in regional economic growth and identifying the likely interregional spillover effects. The first step is to divide China into regions according to their stage of development. The three classifications chosen here are suggested by Zhang and Felmingham (1999) and conform to policy directions of the Chinese government.

The 29 provinces in the PRC were divided into three groups depending on the average value of FDI received by each province over the period 1983-98. The high FDI group (HFDI) had received no less than US\$500 million on average. The provinces qualifying as HFDI are Beijing, Tianjin, Liaoning Shanghai, Jiangsu, Zhejiang, Fujian, Shandong and Guangdong. The medium group (MFDI) received an average annual FDI in the range of US\$100-500 million, and include Hebei, Jilin, Heilongjiang, Anhui, Jiangxi, Henan, Hubei, Hunan, Guangxi, Hainan, Sichuan and Shanxi. Provinces receiving less than US $\$ 100$ million comprised Shaanxi, Inner Mongolia, Guizhuzo, Yunnan, Xinjiang, Gansu, Qinghai and Ningxia. These are defined as the low FDI group (LFDI). The HFDI, MFDI and LFDI groups coincide with the Eastern, the Central and the Western geographical regions of China.

Three models are estimated in this study. Estimation of the first model, based on Equation 12.12, examines the contribution of export expansion to economic growth for China as a whole and the three regions (the HFDI, MFDI and LFDI regions), respectively. Estimation of the second model based on Equation 12.16 allows identification of differences in the nature as well as the 


\section{Dilemmas of China's Growth in the Twenty-First Century}

magnitude of the contribution of export expansion to growth among the three regions of China. The econometric forms of Equations 12.12 and 12.16 are written as

$$
\begin{aligned}
& Y=\alpha_{1}{ }^{-}+\alpha_{2} I^{*}+\alpha_{3} \dot{L}_{0}+\gamma \dot{X}+\varepsilon_{1 \bullet} \\
& Y=\alpha_{1}{ }^{-}+\alpha_{2} I^{*}+\alpha_{3} L+\theta(\mathrm{Y}-\mathrm{X})(X / \mathrm{X})+(\delta / 1+\delta) \dot{X}+\varepsilon_{1}(12.18)
\end{aligned}
$$

Both models, Equations 12.17 and 12.18, capture the contribution of export expansion to growth through two channels: sector-externality and factorproductivity effects. The second model is differentiated from the first in that it allows for the separate identification of these two effects. The sector-externality effect measures the positive externality of the export sector on the non-export sector. The factor-productivity effect measures the gain due to the higher productivity of factors in the export sector.

The third model applied in this study is designed to test the spillover effects from the HFDI region to the MFDI and LFDI regions and from the MFDI to the LFDI region. This model is based on the fact that the degree of economic development differs substantially across the three regions of China. Trade and FDI are heavily concentrated in the coastal region. The Chinese government has strongly encouraged the HFDI region to establish close links with the rest of the world. Subsequently, the East is the richest region, followed by the MFDI region. The LFDI region is backward with a low degree of openness. Our assumption is that there are positive spillover effects from the richer to the poorer regions.

The growth pole theory forms the theoretical basis for Model 12.3. Regional development theories and policies have largely focused on the dynamic interactive process between the relatively developed regions, termed the core, and the less developed regions, termed the periphery. The industrialised regions refer to the main economic centres or areas while the less industrialised regions refer to countryside or far inland areas. According to Hirschman (1958), the development process is a chain of disequilibria. Uneven growth between different regions is inevitable and occurs frequently. The different regions interact through input-output linkages and other relationships. The input demand effects and output supply effects are important interactive effects between different regions. ${ }^{5}$ Both backward and forward linkage effects are realised through input and output flows, including labour migration and trade in intermediate and final products. In addition to input-output relations, interregional capital flows, technological transmission, consumer market demand and income remittances are important mechanisms through which interactive impacts between regions are achieved.

A number of studies have shown that there are positive and negative transmission effects (Richardson 1976; Gaile 1980; Wilber and Francis 1986; Hughes and Holland 1994; Barkely, Henry and Bao 1996). The positive impacts 


\section{Regional development in China}

are known as the spread effect, which refers to the diffusion of growth from advanced to backward regions. The spread effect tends to promote economic development and increase income per capita in the backward areas and eventually leads to a convergence of interregional development. Backwash effects, on the contrary, are the unfavourable effects on the poor regions, of interregional interdependence. These include the migration of educated, skilled and technical workers and the flows of capital from poor to rich regions, and unfavourable changes in the terms of trade between primary and manufactured products. This seems likely to impede economic development in backward regions.

The third model is formulated to test interregional spillovers in the context of China. For this purpose, the following equations are applied.

$$
\begin{aligned}
& \dot{Y}_{\mathrm{M}}=\alpha_{11} \mathrm{I}_{\mathrm{M}}+\alpha_{12} \mathrm{I}_{\mathrm{M}}^{*}+\alpha_{13} \dot{L}_{\mathrm{M}}+\gamma_{11} \mathrm{X}_{\mathrm{M}}+\beta_{11} \dot{Y}_{\mathrm{H}}+\varepsilon_{11} \\
& \dot{Y}_{\mathrm{L}}=\alpha_{21} \mathrm{I}_{\mathrm{L}}+\alpha_{22} \mathrm{I}_{\mathrm{L}}{ }_{\mathrm{L}}+\alpha_{23} \dot{L}_{\mathrm{L}}+\gamma_{21} \mathrm{X}_{\mathrm{L}}+\beta_{21} \dot{Y}_{\mathrm{H}}+\varepsilon_{21} \\
& \dot{Y}_{\mathrm{L}}=\alpha_{31} \mathrm{I}_{\mathrm{L}}+\alpha_{32} \mathrm{I}_{\mathrm{L}}{ }_{\mathrm{L}}+\alpha_{33} \dot{L}_{\mathrm{L}}+\gamma_{31} \mathrm{X}_{\mathrm{L}}+\beta_{31} \dot{Y}_{\mathrm{M}}+\varepsilon_{31}
\end{aligned}
$$

In Equations $12.19,12.20$ and 12.21, $Y, \mathrm{I}^{-}, \mathrm{I}^{*}, L$ and $X$ are, respectively, the change of GDP, domestic investment, FDI, the growth of the labour force and the change in exports. All variables are in real terms expressed in billions of yuan RMB, except for labour which is measured in number of workers. Subscripts $H, M$ and $L$ with respect to the variables stand for the HFDI, MFDI and LFDI regions. $\dot{Y}_{\mathrm{H}}, \dot{Y}_{\mathrm{M}}$ in Equations 12.19, 12.20 and 12.21 are the average first differences of GDP in the HFDI and MFDI regions, respectively, used as an indicator of interregional spillover effects. Our assumption here is that the spillover from the HFDI region is evenly distributed to the MFDI and the LFDI regions, but that feedback from the MFDI and the LFDI provinces to the HFDI region is negligible. If the coefficients of $Y_{\mathrm{H}}$, $\dot{Y}_{M}\left(\beta_{11}, \beta_{21}, \beta_{31}\right)$ in Equations $12.19,12.20$ and 12.21 are positive and significant, then we can conclude that there is spillover from the HFDI to the MFDI and LFDI regions, or from the MFDI region to the LFDI region. In addition, we try the change of exports $(\dot{X})$ and FDI $\left(\mathrm{I}^{*}\right)$ as indicators of interregional spillover effects.

The regional level panel data used overcome a number of problems encountered with either cross-section or time-series data alone. The advantages of panel data are varied and include an increased number of observations, more variability and information and the possibility of treating two dimensions (cross-section and time-series) separately.

All the regressions are performed using Limdep software. The estimation results of fixed effect and random effect models are obtained for panel data. Test results from the fixed effect model may raise questions about the endogeneity of export expansion or the variable as a determinant of GDP 


\section{Dilemmas of China's Growth in the Twenty-First Century}

growth. This problem may be solved by a further step where the models are estimated by simultaneous methods.

\section{Results and interpretation}

The results obtained from the estimation of Equation 12.12 are reported in Table 12.1 for the entire sample of 29 provinces as well as the sub-samples for the three regions. A preliminary test for the correlation between variable FDI and $X$ is also performed and it is found that the correlation coefficient is 0.5120 with t-test of 12.48 for the whole sample and 0.4647 (5.70), 0.1511 ( 2.12), -0.2115 ( 2.35), for the HFDI, the MFDI and the LFDI, respectively (t-ratio in brackets). ${ }^{6}$ These correlation coefficients are all significant at the five per cent level, but the correlation coefficients are not high enough to be of concern regarding the reliability of results.

The study uses panel data so that both random effect and fixed effect models are estimated. The random effects model is rejected in favour of the fixed effect model for the whole sample by the Hausman test $\chi^{2}(3)=21.45, \chi^{2}(4)=19.36$ for the Neoclassical model and Model 12.1 (Equation 12.17), respectively. However, for the sake of simplicity, only the results from estimation of the fixed effect model are presented here for the whole sample. ${ }^{7}$ The results from within estimates (fixed effects) and random effects are listed in Appendix 12.1. Fixed effect models are rejected in favour of the random effect models for all three regions since the Hausman test $\left(\chi^{2}\right)$ with four degrees of freedom are $7.45,2.04,1.58$ for the HFDI, the MFDI and the LFDI groups, respectively. The results from the fixed effect model for the three regions are also listed in Appendix 12.1.

The results listed in columns two and three are the two specifications of the regression equation for the whole sample. Column two contains the results from the modified conventional Neoclassical model (including the FDI in the equation) assuming $\gamma=0$ in our Equation 12.17. It investigates GDP growth based on domestic investment, FDI, and the growth of labour only. The test results for Model 12.1 are presented in column three. The coefficients of domestic investment, FDI and the growth of labour are positive and significant in both columns (columns two and three). These results indicate not only that the domestically-financed investment and growth of labour are the major factors in explaining Chinese economic growth, but also that the role of inward FDI cannot be ignored. This is supported by the fact that inward FDI in China grew on average at 35 per cent per annum, increasing from US $\$ 1,258$ million to US $\$ 45,463$ million between 1984 and 1998 . FDI accounted for 10.3 per cent and 9.1 per cent of the total domestic capital formation in China in 1997 and 1998, respectively (SSB 1998 and 1999).

The adjusted $\mathrm{R}^{2}$ is higher in Model 12.1 than in the modified Neoclassical 


\section{Table 12.1 Regression results for Model 12.1, panel data}

\begin{tabular}{|c|c|c|c|c|c|}
\hline \multicolumn{5}{|c|}{ Dependent variable $\dot{Y}: \dot{Y}=\alpha_{1}{ }^{-}+\left.\alpha_{2}\right|^{*}+\alpha_{3} \dot{L}+\gamma \dot{X}+\varepsilon_{1}$} & \multirow[t]{2}{*}{$(12.17)$} \\
\hline $\begin{array}{l}\text { Variable } \\
\text { (parameter) }\end{array}$ & Whole sample & HFDI region & MFDI region & LFDI region & \\
\hline \multirow[t]{2}{*}{1} & 2 & 3 & 4 & 5 & 6 \\
\hline & $\begin{array}{l}\text { Neoclassical } \\
\text { model } \\
\text { (Fixed effect) }\end{array}$ & $\begin{array}{l}\text { Equ. } 12.17 \\
\text { (Fixed effect) }\end{array}$ & $\begin{array}{l}\text { Equ. } 12.17 \\
\text { Random } \\
\text { effect } \\
\text { model }\end{array}$ & $\begin{array}{l}\text { Equ. } 12.17 \\
\text { Random } \\
\text { effect } \\
\text { model }\end{array}$ & $\begin{array}{l}\text { Equ. } 12.17 \\
\text { Random } \\
\text { effect } \\
\text { model }\end{array}$ \\
\hline$\left(\alpha_{1}\right)$ & $\begin{array}{c}0.222 \\
(10.932)^{\star}\end{array}$ & $\begin{array}{c}0.225 \\
(11.056)^{*}\end{array}$ & $\begin{array}{c}0.175 \\
(3.834)^{*}\end{array}$ & $\begin{array}{c}0.165 \\
(2.795)^{*}\end{array}$ & $\begin{array}{l}0.059 \\
(0.059)^{\star}\end{array}$ \\
\hline $\mathrm{l}^{\star}\left(\alpha_{2}\right)$ & $\begin{array}{c}0.245 \\
(3.956)^{\star}\end{array}$ & $\begin{array}{c}0.197 \\
(2.850)^{*}\end{array}$ & $\begin{array}{c}0.267 \\
(2.132)^{*}\end{array}$ & $\begin{array}{c}0.906 \\
(2.488)^{*}\end{array}$ & $\begin{array}{c}1.422 \\
(4.113)^{k}\end{array}$ \\
\hline$\left.\dot{L}_{(} \alpha_{3}\right)$ & $\begin{array}{c}0.465 \\
(5.449)^{\star}\end{array}$ & $\begin{array}{c}0.442 \\
(5.112)^{*}\end{array}$ & $\begin{array}{r}0.394^{*} \\
(2.833)\end{array}$ & $\begin{array}{c}0.101 \\
(0.445)\end{array}$ & $\begin{array}{c}-0.090 \\
(-0.250)\end{array}$ \\
\hline$\stackrel{\dot{x}}{(\gamma)}$ & $\begin{array}{l}. . \\
. .\end{array}$ & $\begin{array}{c}0.073 \\
(1.659)^{k *}\end{array}$ & $\begin{array}{c}0.071 \\
(1.443)\end{array}$ & $\begin{array}{c}-0.143 \\
(-0.504)\end{array}$ & $\begin{array}{c}-0.290 \\
(-1.541)\end{array}$ \\
\hline constant & $\begin{array}{c}-3.446 \\
(-0.389)\end{array}$ & $\begin{array}{c}-3.343 \\
(-0.378)\end{array}$ & $\begin{array}{l}24.570 \\
(0.770)\end{array}$ & $\begin{array}{c}28.350 \\
(0.940)\end{array}$ & $\begin{array}{c}85.703 \\
(0.420)\end{array}$ \\
\hline$\left(\right.$ Adj) $R^{2}$ & 0.570 & 0.577 & 0.625 & 0.462 & 0.898 \\
\hline No. of obs & 435 & 435 & 135 & 180 & 120 \\
\hline \multicolumn{3}{|c|}{ Hausman test $\chi^{2}(3)=21.45^{\star} \chi^{2}(4)=19.36^{\star}$} & $\chi^{2}(4)=7.45$ & $\chi^{2}(4)=2.04$ & $\chi^{2}(4)=1.58$ \\
\hline
\end{tabular}

Notes: T-ratio is in brackets.

${ }^{*}$ and ${ }^{* *}$ represent $5 \%$ and $10 \%$ significant level respectively.

model, indicating that the explanatory power of Model 12.1 improves when export growth is modelled as an explanation for GDP growth for China as a whole. The coefficient of $\dot{X}(\gamma)$, which picks up both the sector externality effect and the factor-productivity effect, is positive and significant at the ten per cent level in Model 12.1. These findings support the existence of the combined effects of export growth and also confirm the important role of exports in the economic development of China. ${ }^{8}$

The test results reveal different stories for the HFDI, the MFDI and the LFDI regions. For each region, domestic investment and FDI are significantly different from zero, supporting the Neoclassical view that economic growth is influenced by capital formation. In relation to labour, the coefficient of growth of labour $\left(\alpha_{3}\right)$ is positive and significant in the HFDI region in particular. This implies that the labour surplus was not the prevalent explanation in the coastal provinces. On the other hand, the coefficient of labour growth is positive in the MFDI region and negative in the LFDI region. However, both the coefficients of labour are insignificant. One explanation is that there is high or 


\section{Dilemmas of China's Growth in the Twenty-First Century}

disguised unemployment in these inland regions, especially in the countryside. Another explanation involves the strong trend of migration from the MFDI and the LFDI region to the HFDI region since the early 1980s. It is estimated that in 199712.9 million labourers migrated from the countryside to the provincial cities, while 5.9 million and 2.9 million labourers migrated from the inland regions to the coastal areas. The absorption of these unemployed labourers into the eastern economy has tended to contribute to lower unemployment and the higher growth of the inland regions (Sun 2000).

Columns four, five and six of Table 12.1 show that the coefficients of $\dot{X}$ vary across the three regions. The coefficient of export growth is positive and the t-ratio is higher than 1 only in the HFDI region. The coefficient of $X(\gamma)$ is -0.143 , which is not significant for the MFDI region. These estimates indicate that the relationship between exports and GDP growth does not seem to be particularly strong in the East if the relationship is examined in the context of each region separately. However, export expansion is not related to economic growth for the MFDI region. The statistical results from column six of Table 12.1 show that export growth has a negative impact on GDP growth in the LFDI region. This may be due to the lack of available infrastructure in that region, a problem exacerbated by the diversion of resources away from the non-export sector in that region.

These findings indicate that there are substantial differences in the relationship between exports and growth among regions. This is also supported by Lee's (1994) study of much earlier data.

The results from Equation 12.18 for the separate effects of sectoral externality and factor productivity are reported on Table 12.2. The fixed effect model (between group) estimation results are listed in column two of for the whole sample. The Hausman test has $\chi^{2}=18.92$ with five degrees of freedom suggesting that the fixed effect model estimators are consistent and efficient. But for all regional tests, the Hausman test results of $\chi^{2}(5)=7.14$, $\chi^{2}(5)=2.60$, and $\chi^{2}(5)=0.54$ for the three regions are insignificant, resulting in a clear rejection of the null hypothesis of the fixed effect against the random effect model. The results from within estimates of the fixed effect model and the random effect model for the whole sample and the fixed effect estimators for regional estimation are listed in Appendix 12.2.

The results in column two of Table 12.2 for Equation 12.18 suggest that the marginal productivities of domestically-financed capital, FDI and the marginal productivity of labour are positive and statistically significant. These findings confirm the results obtained in Table 12.1. The differential marginal productivity parameter $\delta$ is $0.0622(\delta / 1+\delta=0.0586)$, indicating that factors used in the export sector are 6.22 per cent more productive than those used in the non-export sector. But this parameter is not significant. No conclusion can 


\section{Regional development in China}

be drawn from the observation that marginal productivity is higher in the export sector than the non-export sector for the whole sample. The parameter $\theta$ representing the externality effect of the export sector on the non-export sector is 0.015 , with t-ratio not significant. This suggests that there is no positive impact of the export sector on the non-export sector for China as a whole.

The regional estimation results in columns three, four and five of Table 12.2 indicate that the marginal productivity of foreign capital is both positive and significantly different from zero for all three regions. The results also indicate that marginal productivity of domestically-financed capital is significantly different from zero in the HFDI and the MFDI regions. The statistical results for FDI both from Table 12.1 and Table 12.2 confirm that economic growth is largely dependent on FDI whether it is examined in the context of China as a whole or for the three individual regions. The highest coefficient of FDI is in the LFDI region, implying that the marginal productivity of FDI in the non-export sector is highest in that region. This reveals that the growth of the west relies substantially on capital formation and (most likely) capital expenditure on infrastructure.

In the HFDI region, the differential marginal productivity parameter $\delta$ is positive but not significant $((\delta / 1+\delta)=0.0246)$, suggesting that there is no difference between marginal productivity in the export and the non-export sectors. This can be explained by the more advanced industrial structure and the greater openness of the coastal economy. Openness in trade is increasingly being viewed as an important mechanism for steady economic growth in less industrialised countries. ${ }^{9}$ China's economy has opened up significantly since 1979. The volume of exports and imports as a percentage of GDP increased from 8 per cent in 1979 to 34 per cent in 1998 (SSB 1980 and 1998). It is noted that the openness of the Chinese economy is biased towards the coastal area. However, the externality effect of exports on the non-export sector represented by $\theta(0.0754)$ is positive and significant, implying that the externality from the export to the non-export sector does exist for the Coastal provinces. This may be explained by the emergence of more foreign invested enterprises (FIEs) along the coast. Their involvement in the export sector may have impacted on the non-export sector in the East. This argument will be investigated in a further study.

The statistical results in column four of Table 12.2 show that there is neither a factor productivity difference nor an externality effect from the export to the non-export sector for the MFDI region.

The results for the LFDI region are reported in column five of Table 12.2. The finding is that marginal productivity is higher in the non-export sector, as indicated by the negative and significant sign of $\delta((\delta / 1+\delta)=-0.073)$. 


\section{Dilemmas of China's Growth in the Twenty-First Century}

\begin{tabular}{|c|c|c|c|c|}
\hline Table 12.2 & Regressio & on results for $\mathrm{Mc}$ & odel 12.2, panel & data \\
\hline Dependent ve & ariable $\dot{Y}: \dot{Y}=\alpha$ & $L_{1}+\left.\alpha_{2}\right|^{*}+\alpha_{3} \dot{L}+$ & $\theta(Y-X)(\dot{X} / X)+(\delta$ & $(1+\delta) \dot{X}+\varepsilon_{2}$ \\
\hline $\begin{array}{l}\text { Variable } \\
\text { (parameter) }\end{array}$ & Whole sample & HFDI region & FDI region & LFDl region \\
\hline 1 & $\begin{array}{l}2 \\
\text { Equation } 12.18 \\
\text { Fixed effect }\end{array}$ & $\begin{array}{l}3 \\
\text { Equation } 12.18 \\
\text { Random effect }\end{array}$ & $\begin{array}{l}4 \\
\text { Equation } 12.18 \\
\text { Random effect }\end{array}$ & $\begin{array}{l}\mathbf{5} \\
\text { Equation } 12.18 \\
\text { Random effect }\end{array}$ \\
\hline$\left.\stackrel{r}{(} \alpha_{1}\right)$ & $\begin{array}{c}0.223 \\
(10.921)^{\star}\end{array}$ & $\begin{array}{c}0.159 \\
(3.46)^{\star}\end{array}$ & $\begin{array}{l}0.181 \\
(3.342)^{\star}\end{array}$ & $\begin{array}{l}0.061 \\
(1.667)^{\star \star}\end{array}$ \\
\hline$I^{*}\left(\alpha_{2}\right)$ & $\begin{array}{c}0.205 \\
(2.957)^{*}\end{array}$ & $\begin{array}{c}0.297 \\
(2.38)^{\star}\end{array}$ & $\begin{array}{c}0.877 \\
(2.425)^{\star}\end{array}$ & $\begin{array}{c}1.731 \\
(4.331)^{\star}\end{array}$ \\
\hline$\left.\stackrel{\dot{L}}{\alpha_{3}}\right)$ & $\begin{array}{c}0.437 \\
(5.067)^{\star}\end{array}$ & $\begin{array}{c}0.367 \\
(2.658)^{\star}\end{array}$ & $\begin{array}{c}0.185 \\
(0.845)\end{array}$ & $\begin{array}{c}-0.019 \\
(-0.990)\end{array}$ \\
\hline$\stackrel{\dot{X}}{(\delta / 1+\delta)}$ & $\begin{array}{c}0.059 \\
(1.282)\end{array}$ & $\begin{array}{c}0.025 \\
(0.370)\end{array}$ & $\begin{array}{c}-0.239 \\
(-0.890)\end{array}$ & $\begin{array}{c}-0.073 \\
(-2.659)^{*}\end{array}$ \\
\hline $\begin{array}{l}\text { NGX } \\
(\theta)\end{array}$ & $\begin{array}{c}0.015 \\
(1.364)\end{array}$ & $\begin{array}{c}0.075 \\
(2.002)^{*}\end{array}$ & $\begin{array}{c}0.009 \\
(0.560)\end{array}$ & $\begin{array}{c}0.029 \\
(1.293)\end{array}$ \\
\hline constant & $\begin{array}{c}-4.411 \\
(-0.520)\end{array}$ & $\begin{array}{l}20.480 \\
(0.662)\end{array}$ & $\begin{array}{l}17.268 \\
(0.663)\end{array}$ & $\begin{array}{l}29.640 \\
(0.322)\end{array}$ \\
\hline (Adj) $R^{2}$ & 0.572 & 0.641 & 0.463 & 0.898 \\
\hline No. of obs & 435 & 135 & 180 & 120 \\
\hline $\begin{array}{l}\text { Hausman } \\
\text { Test }\end{array}$ & $\chi^{2}(5)=18.92$ & $\chi^{2}(5)=7.14$ & $\chi^{2}(5)=1.17$ & $\chi^{2}(5)=0.54$ \\
\hline
\end{tabular}

Notes: T-ratio is in the bracket

* and ${ }^{* *}$ represent $5 \%$ and $10 \%$ significant level respectively.

Comparatively speaking, the LFDI region is backward and markets are largely domestically-oriented with a low degree of openness. The substantial gap in technology applied to the export and the non-export sector partly explains the deficiency of the export sector in the LFDI group. The test results from Model 12.2 confirm the argument that a certain level of development is necessary before the export sector positively impacts on the non-export sector and overall economic growth.

These findings are consistent with the theoretical hypothesis that the impact of export expansion and FDI on economic growth varies according to regional economic characteristics, including the level of development, economic structure and policy orientations. To a large extent, the differential impact of exports and FDI account for divergent growth performance across different regions. On the other hand, the level of development and the structural characteristics and policy orientation shape the direction and the extent of the impact of 


\section{Regional development in China}

export expansion and FDI. This study therefore confirms that export expansion and economic growth are two interactive processes of economic development. Simultaneous modelling will confirm or deny this absolutely, but it is a matter for further analysis.

The results from the Model 12.3 developed are listed in Table 12.3. Columns two and three contain the test results of spillover effects from the HFDI region to the MFDI and the LFDI regions. Column four shows the results of the spread from the MFDI to the LFDI region. It is noted that the parameters $\left(\beta_{1}, \beta_{2}, \beta_{3}\right)$ are significantly different from zero.

These estimates support the rejection of the hypothesis that there are no spillover effects from the HFDI to the MFDI and the LFDI regions, or from the MFDI to the LFDI region, when the output in the HFDI and the MFDI region $\left(Y_{\mathrm{H}}, \dot{Y}_{\mathrm{M}}\right)$ are used as indicators of interregional spillover effects.

The interregional growth transmission between the HFDI and the MFDI region and between the HFDI and the LFDI can be explained as follows: the eastern region is traditionally more advanced. This is reflected in its industrial structure. It is widely agreed that primary industry comprises a large share of GDP and total employment when the economy is at an early stage of its development (see Richardson 1976; Sun and Dilip 1997; Sun 2000). However, secondary and tertiary industries tend to become more important and account for a larger share of GDP as the economy develops. Industrial structure and the stage of development vary across regions in China. Some basic statistical data supports this view. Table 12.4 provides the share of industries as a percentage of GDP for the three regions in 1997 and 1998. It is found that the share of primary industry in GDP in the HFDI was 13.27 per cent and 12.64 per cent in 1997 and 1998, respectively. These statistics were higher in the MFDI and the LFDI regions, where the primary industry share was 22.64 per cent and 21.37 per cent for the MFDI region, and 25.57 per cent and 24.62 per cent for the LFDI, in 1997 and 1998, respectively. On the contrary, the share of the secondary and tertiary industries as a percentage of GDP were higher in the HFDI region than was the case in the other two regions.

Since the 1980s, the coastal region has been identified as the growth core of the national economy. The regional development policies pursued there have favoured the HFDI region where a series of special preferential policies have been applied. These include tax concessions for the enterprises located in the SEZs and coastal open area, more autonomy in foreign trade and FDI, and a relatively large share of tax income retained by the local government. At the same time, market-oriented economic reforms and the opening of the Chinese market to foreign trade and FDI have progressed far more broadly and deeply in the HFDI region than in the inland regions. More developed markets have contributed to productivity growth and the overall improvement in economic 


\section{Dilemmas of China's Growth in the Twenty-First Century}

\begin{tabular}{|c|c|c|c|}
\hline Table 12.3 & \multicolumn{3}{|c|}{$\begin{array}{l}\text { Regression results for Model } 12.3 \text { (interregional spillover } \\
\text { effects) }\end{array}$} \\
\hline Variables & \multirow{2}{*}{$\begin{array}{l}\text { Equation } 12.19 \\
\text { Spillover from } \\
\text { HFDI to MFDI } \\
\text { (Random effect } \\
\text { model) } \\
2\end{array}$} & \multirow{2}{*}{$\begin{array}{l}\text { Equation } 12.20 \\
\text { Spillover from } \\
\text { HFDl to LFDI } \\
\text { (Fixed effect model) } \\
3\end{array}$} & $\begin{array}{l}\text { Equation } 12.21 \\
\text { Spillover from } \\
\text { MFDI to LFDI } \\
\text { (Fixed effect model) }\end{array}$ \\
\hline 1 & & & 4 \\
\hline$\left(\alpha_{i 1}\right)$ & $\begin{array}{c}0.101 \\
(1.658)^{\star \star}\end{array}$ & $\begin{array}{c}0.118 \\
(4.084)^{*}\end{array}$ & $\begin{array}{c}0.136 \\
(4.957)^{\star}\end{array}$ \\
\hline $\mathrm{I}^{\star}\left(\alpha_{\mathrm{i} 2}\right)$ & $\begin{array}{c}0.262 \\
(0.649)\end{array}$ & $\begin{array}{c}0.536 \\
(2.028)^{\star}\end{array}$ & $\begin{array}{c}0.532 \\
(1.992)^{*}\end{array}$ \\
\hline$\stackrel{\dot{L}}{\left(\alpha_{13}\right)}$ & $\begin{array}{c}0.329 \\
(1.415)\end{array}$ & $\begin{array}{c}0.391 \\
(2.810)^{\star}\end{array}$ & $\begin{array}{c}0.326 \\
(2.406)^{*}\end{array}$ \\
\hline$\stackrel{\dot{X}}{\left(\gamma_{i}\right)}$ & $\begin{array}{c}-0.079 \\
(-0.290)\end{array}$ & $\begin{array}{c}-0.127 \\
(-0.547)\end{array}$ & $\begin{array}{c}-0.124 \\
(-0.532)\end{array}$ \\
\hline $\begin{array}{l}Y \\
\left(B_{i}\right)\end{array}$ & $\begin{array}{c}0.355 \\
(3.937)^{*}\end{array}$ & $\begin{array}{c}0.073 \\
(3.104)^{*}\end{array}$ & $\begin{array}{c}0.124 \\
(2.920)^{*}\end{array}$ \\
\hline constant & $\begin{array}{l}-22.810 \\
(-0.656)\end{array}$ & $\begin{array}{c}-8.463 \\
(-1.270)\end{array}$ & $\begin{array}{c}-7.883 \\
(-1.174)\end{array}$ \\
\hline$(\mathrm{Adj}) \mathrm{R}^{2}$ & 0.505 & 0.824 & 0.823 \\
\hline No. of obs & 180 & 120 & 120 \\
\hline Hausman test & $\chi^{2}(5)=2.11$ & $\chi^{2}(5)=20.04$ & $\chi^{2}(5)=18.60$ \\
\hline
\end{tabular}

Notes: T-ratio is in bracket

*and ${ }^{* *}$ represent $5 \%$ and $10 \%$ significant level respectively.

efficiency of the HFDI region. More importantly, the Chinese central government has committed a large amount of capital in the HFDI provinces to improve infrastructure, especially the transportation system and telecommunication facilities. These incentives have provided a better investment environment, attracting FDI to this region. It is widely recognised that the HFDI area is more open than the MFDI and LFDI regions. ${ }^{10}$

Input-output linkages are important reasons behind interregional spillover effects. Input demand, also termed the backward linkage effect, can stimulate growth in the production of intermediate products and materials. With regard to the spatial distribution pattern of Chinese industries, the LFDI and MFDI regions are largely oriented towards primary industries, such as agriculture, mining and forestry, while manufacturing and services dominate in the east. Coastal economic growth, since the opening of the Chinese economy, has created a strong demand for raw materials and intermediate products from the inland regions, transmitting a growth stimulus from the HFDI provinces to the MFDI and LFDI regions. Further government policies have encouraged 


\section{Regional development in China}

the use of domestic resources in producing exports.

The measure of the spillover effects $\beta_{1}(0.3551)$ from the HFDI to the MFDI is higher than $\beta_{2}(0.073)$ which represents the spillover effects from the HFDI to the LFDI. This suggests that the dimension of spillover effects from the HFDI to the MFDI provinces is larger than the spillover to the LFDI. This can be explained by the spatial location and the degree of similarity of the economic structures in the HFDI and the MFDI regions. The MFDI region is more open and more closely linked with the eastern economy in comparison with the LFDI provinces. As described, $\dot{X}$ and FDI are also employed in the model instead of $\dot{Y}$ as indicators for spillover effects, but the test results fail to show the presence of interregional spillover effects. A reasonable explanation is that output in the export sector and the activities involving the FIEs in the HFDI regions are not significant enough to impact on the economic development of other regions, although the previous analysis shows FDI and exports are the major factors in coastal economic growth.

\section{Conclusion}

China has experienced remarkable economic growth since the 1980s. Economic reform, export expansion, FDI, SEZs and joint ventures have all affected the three main regions of China. The empirical study in this chapter analysed the impact of exports and FDI on regional economic growth. In addition, the interregional spillover effect model was applied, based on growth pole theory, to investigate the transmission of growth from the comparatively rich HFDI region to the MFDI and the LFDI, and from the MFDI to the LFDI regions.

Three models were developed. The first two investigated the effects of export growth, FDI, domestic investment and labour growth on economic growth in the context of China as a whole as well as the three individual regions. FDI was found to be significant in all cases and all three models established that the contribution of FDI to overall economic growth is critical. Another finding was that exports have a positive and significant impact on Chinese economic growth. The positive externality from the export to the non-export sector was evident in the HFDI region. These findings indicate that the contribution of export growth to overall economic growth is important.

When the study focuses on the regional development of the three areas, it is clear that the role of export expansion varies across all three regions. Export growth significantly contributed to economic growth on the coast, while its impact was insignificant in the MFDI region and negative or marginally significant in the LFDI region. These results indicate that the role of exports in economic development depends largely on the individual situation of each region. The level of development and industrial structure, the policy orientation 
Dilemmas of China's Growth in the Twenty-First Century

Table $12.4 \quad$ Industrial structure of the HFDI, MFDI and LFDI regions

\begin{tabular}{lllllll}
\hline & \multicolumn{2}{l}{$\begin{array}{l}\text { Primary industry } \\
\text { (\% of GDP) }\end{array}$} & \multicolumn{2}{l}{$\begin{array}{l}\text { Secondary industry } \\
\text { (\% of GDP) }\end{array}$} & \multicolumn{2}{l}{ Tertiary industry } \\
& $\mathbf{1 \%}$ of GDP) & \\
& 1997 & 1998 & $\mathbf{1 9 9 7}$ & $\mathbf{1 9 9 8}$ & $\mathbf{1 9 9 7}$ & 1998 \\
HFDI region & 13.27 & 12.64 & 48.94 & 48.41 & 37.68 & 38.95 \\
MFDI region & 22.64 & 21.37 & 46.34 & 46.27 & 31.09 & 32.28 \\
LFDI region & 25.57 & 24.62 & 41.78 & 41.82 & 32.69 & 33.55 \\
\hline
\end{tabular}

Source: SSB, 1998 and 1999. Statistical Yearbook of China, China Statistical Publishing House, Beijing.

and the degree of openness are quite different among the three regions. Without attaining a certain level of development and openness, exports are unlikely to change economic growth effectively and will fail to act as a driving force in economic growth.

The spillover test results clearly indicate that economic growth in the HFDI does spread to the MFDI and the LFDI regions. This positive growth transmission spreads from the comparatively rich coastal region to the inland regions through input-output linkage effects and the absorption of disguised unemployment. This result has important implications for policy. If the HFDI region plays the role of a growth core, the policies applied in the HFDI region will not only promote productivity and facilitate growth in that region, but will also increase economic development in inland regions. At the same time, more open policies should apply to the inland regions at this stage of their development. Policies promoting export performance and attracting FDI are required. The open door policy should extend as far as possible to the inland regions, where there is huge growth potential. The inland regions should have at the very least, similar development policies and incentives as those applying to the high FDI recipients. Regional discrimination policy should be eliminated. In addition, the central government should improve infrastructure in the MFDI and LFDI regions so as to help them achieve a minimum level of development within the shortest period of time. These measures promise to lessen the gap between different regions in respect of their rate of economic development, and to facilitate its spread from the coastal to the inland regions. 
Regional development in China

\section{Appendix 12.1}

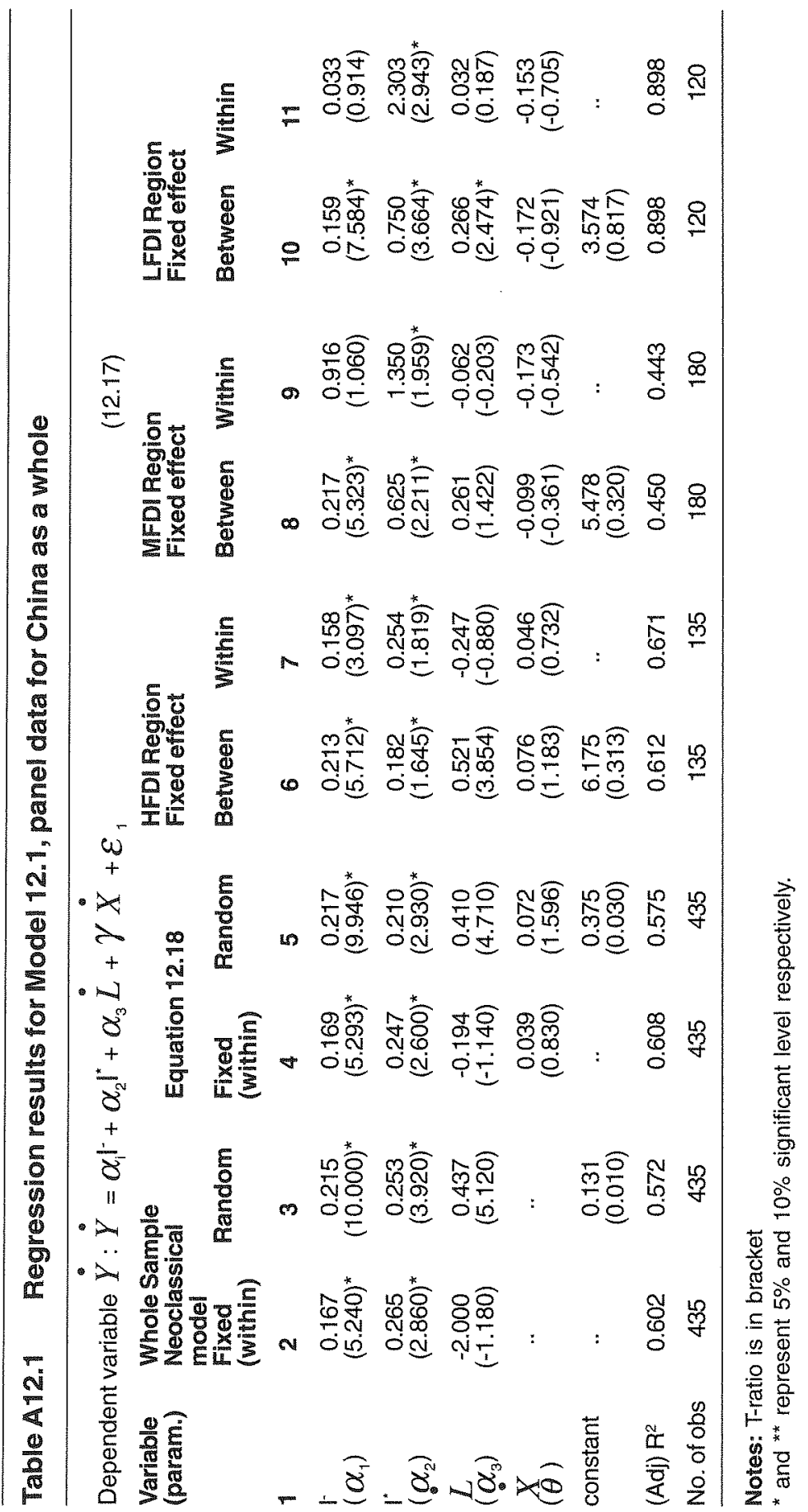


Dilemmas of China's Growth in the Twenty-First Century

\section{Appendix 12.2}

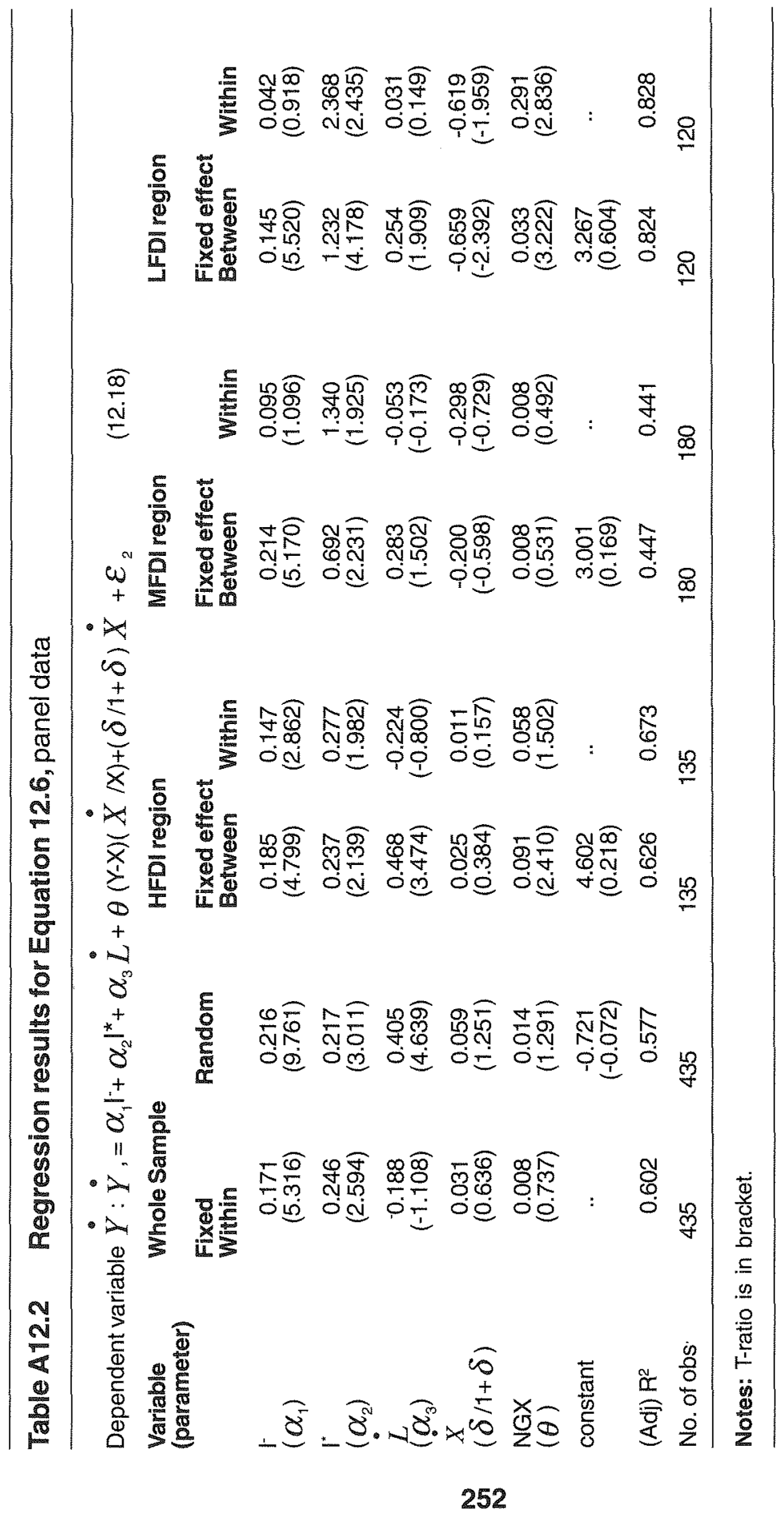




\section{Regional development in China}

\section{Notes}

1 This indicates China's spectacular growth.

2 See details in methodology for grouping method.

$3 \dot{Y}=\alpha_{1} \mathrm{I}^{-}+\alpha_{2} \mathrm{I}^{*}+\alpha_{3} \dot{L}$

4 The data on Chinese provincial GDP, CPI, domestic investment, FDI, population and exports from 1985 to 1995 are taken from China's Regional Economy after Seventeen Years of Reform and Opening up, published by the China Statistical Publishing House in 1996. The above-mentioned data for 1983, 1984 and 1996-98 are drawn from The Statistical Yearbook of China for various years, published by the China Statistical Publishing House.

5 The input demand effects and output supply effects are also known as the backward linkage effects and forward linkage effects, respectively.

$6 \mathrm{~T}=\mathrm{r} / \sqrt{\left(1-r^{2}\right) /(n-2)}$ distributed according to the $\mathrm{t}$-distribution.

7 For the fixed effect model, there are two sets of results. One is constrained least squares regression (between estimation) and the other is the least squares dummy variable model (within estimation). The former is estimated by simple OLS assuming all individual specific constants are equal. The latter is estimated by partitioned OLS with individual specific constant terms (no overall constant).

8 Refers to a sector externality and factor productivity effects.

9 Openness is defined as the ratio of the sum of exports and imports to GDP.

10 The eastern region (HFDI) is found to have the highest degree of openness in several studies (Lee 1994; Sun and Dilip 1997; Sun 2000.) 